\title{
Gender analysis in forestry research Looking back and thinking ahead
}

\author{
Yen Hoang Mai', Esther Mwangi' and Melinda Wan'
}

\section{Key messages}

- Between 2001-2011, the evaluation of men's and women's participation in community forestry initiatives and the commercialising of forest products and market access dominated gender-focused forestry research.

- Community forestry studies were mostly conducted in South Asia, while market access studies predominated in Africa. Most community forestry studies took place in India and Nepal, likely due to a long pattern of devolution reforms in forest management in the region. Market access studies were motivated by the focus on poverty reduction in the 1990s.

- Integrating gender into forest research is constrained by the broad perception that forestry is a male-dominated profession, lack of clarity among researchers about gender and a lack of technical skills, interest and/or awareness of gender.

- Women's involvement is not a foregone conclusion. On the one hand, some women have little interest in forest management; on the other, casual attempts to include women can simply add to their labour burden.

- Further research is needed on the nature and quality of governance arrangements; the dynamics and division of labour between men and women in mixed forest user-groups; how to transform incentives and attitudes of forestry officials; replicating 'critical mass' studies in settings other than Nepal and India; the implications of global processes; and interventions and trends on women's relative participation in decision making and benefits capture.

\section{Introduction}

Climate change, energy security and food security are overarching processes that have renewed focus on the world's forests. However, when it comes to moderating the impact of these broad processes on forests and people, gender inequalities are increasingly viewed as a weak link. Indeed, excluding women from their fair share of benefits and a meaningful role in decisions may undermine intended outcomes under initiatives such as Reducing Emissions from Deforestation and Forest Degradation (REDD).

Research can generate knowledge on how to respond to the needs, capabilities and priorities of both men and women. Despite many gender studies on forestry, however, broad reviews are lacking. To address this gap, several CIFOR researchers synthesised research and policy lessons from diverse forestry settings gleaned from 121 peerreviewed publications, highlighting approaches to the integration of gender analysis into forestry research, as well as constraints and areas for further research. This Infobrief summarises key findings of their study.

The majority of gender research in forestry was conducted in Asia (52 publications) and Africa (41 publications), and less in Latin America (22 publications). The lower count for Latin America may have been influenced by the exclusion of articles written in languages other than English. About eight more articles are at a global or regional scale, which did not identify the location of the study (see Figure 1).

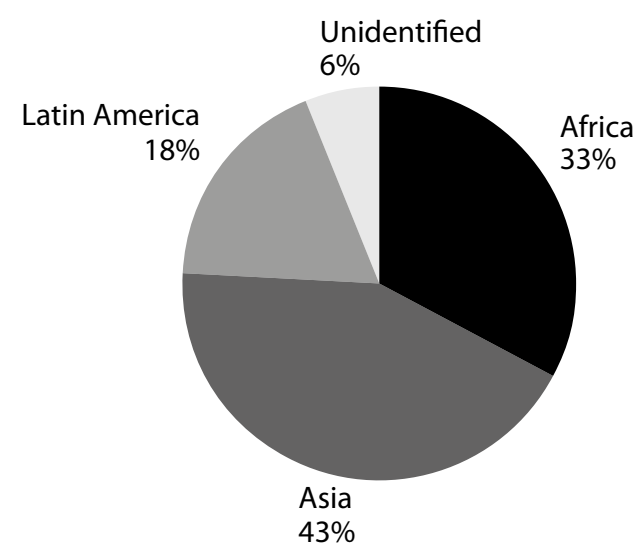

Figure 1. Geographical coverage of women, gender and forests publications from 2000 - mid 2011

\section{Benefits of incorporating gender in forestry research and management}

Engaging women in forest management improves prospects for sustainable forest management, ensuring benefits are distributed equitably and enhancing the efficiency of policy implementation. 
Efficiency: The inclusion of women in executive committees in Nepal and India helped community forest management groups frame more acceptable extraction and protection rules; they also helped decrease violations by the community (Agarwal 2009, 2010a). In addition, since women sometimes noticed illegal cuttings missed by male guards, the inclusion of women in management also improved forest protection.

Equity: Engaging both women and men in forest management empowers marginalised groups, enabling them to voice and act on their needs and preferences (Agarwal 2009, 2010a). Through adaptive collaborative management, researchers also helped increase the decision making and bargaining power of marginalised groups, especially women (Colfer 2005a, 2005b).

Policy: Ignoring gender in policy research may distort the understanding of human impacts on resource management, hinder forestry planning and skew resource allocation (FAO 2007, PRB 2001). Conversely, studying and incorporating the knowledge of both men and women helps generate more accurate and clearer research results (Hovorka 1998).

\section{Factors influencing the inclusion of gender in forestry research}

Despite the best of intentions, researchers may not include gender analysis in their work for a variety of reasons.

Lack of understanding of the gender concept, as well as skewed interest and skills among researchers, undermined the use of gender analysis; a community of practice across research teams made gender analysis more likely (Magnus 2003). In CIFOR's projects from the late 1990s to 2008-2009, incorporating gender depended on the purpose and topic of research; the level of individual interest in gender analysis among researchers; and donor requirements that supported the research. Moreover, in the CIFOR projects, including gender equated to either a focus only on women or to the collection of sex-disaggregated data: little effort was made to understand the drivers of gendered relationships (Mai and Mwangi, in press).

In some cases, researchers incorporated gender if they knew its omission would skew results. For example, CIFOR research into non-timber forest products (NTFPs) recognised gender as a critical variable, targeting both men and women during data collection, analysis and reporting (Alexiades and Shanley 2004, Kusters and Belcher 2004, Perez et al. 2002, Sunderland and Ndoye 2004).

The complexity of gender analysis also thwarts its inclusion in research. Gender-responsive analysis must be attuned to the complexities of such factors as class, race, ethnicity, religion and age, as well as to the overall social context and its influence over bargaining positions (Reeves and Baden 2000). Finally, many cultures typically view forests as a male domain, making it more difficult to include women in management and decision making (Gurung 2002, Lyren 2006, Watson 2005). For example, timber extraction and management - the most lucrative areas - continue to be maledominated. A study in 10 African countries found no women in professional and management positions (FAO 2007).

\section{Thematic coverage of gender research}

Among 10 categories of topics, commonly studied areas included participatory forestry, livelihoods issues (especially market access) and gendered perceptions of forest management (see Figure 2). Over the past decade, forest governance and benefits capture were

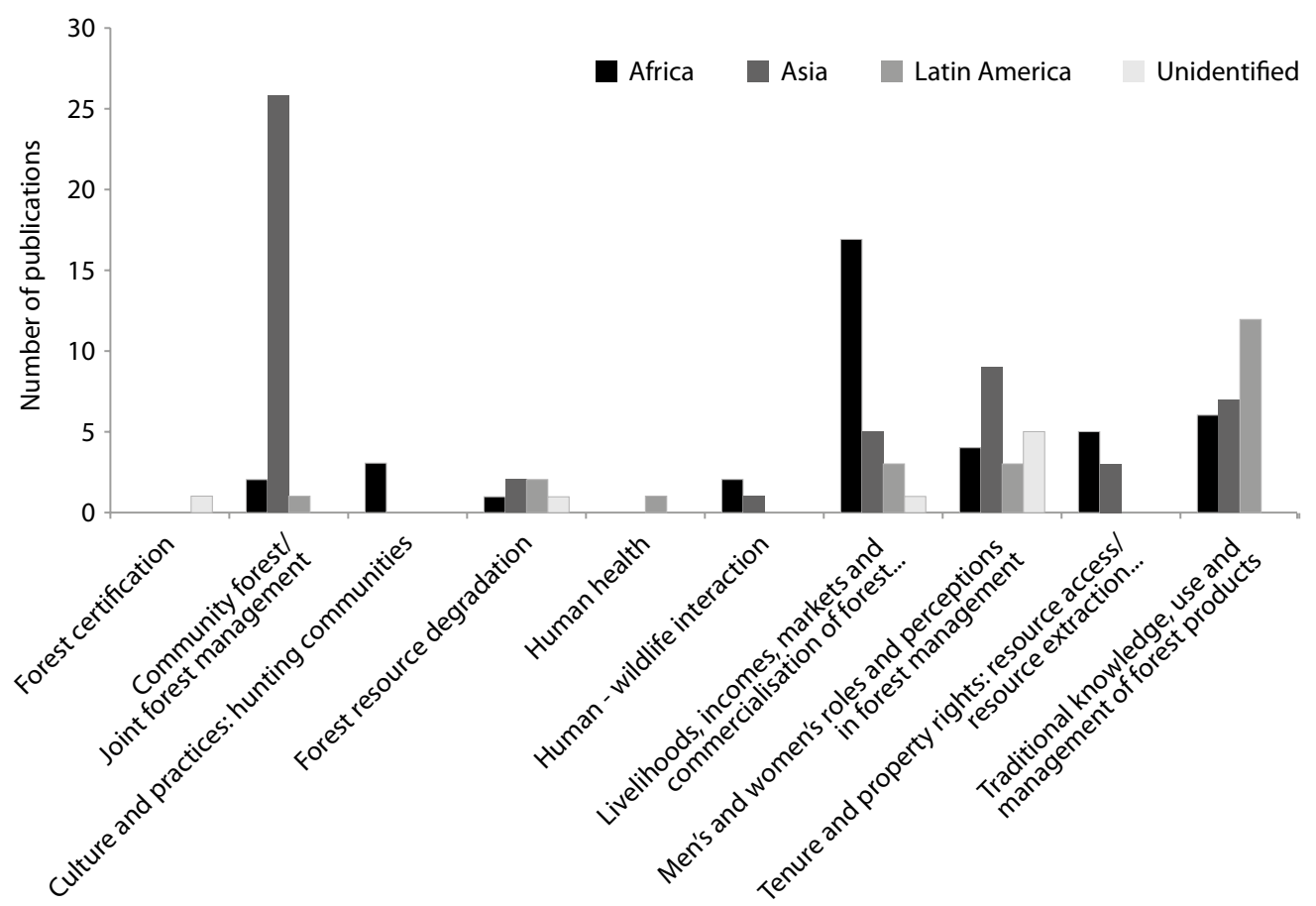

Figure 2. Thematic areas of publications from 2000 - mid 2011 
the main interest; this is no surprise given that decentralisation reforms in Africa, Asia and Latin America have shifted the onus of forest management onto lower levels of government (Colfer and Capistrano 2005, Ribot and Larson 2005). Gender-focused research examined the extent to which men's and women's relative participation in forest management responded to devolving governance, and how such programmes affected women's livelihoods.

Poverty reduction strategies, including concern for access to markets, were another major trend in the 1990s (World Bank 2000). In the forestry sector, the trend led researchers to examine factors that influence the commercialisation of forest products, as well as the relative participation of men and women in markets. While tenure and property rights were a popular topic, human health and forest certification were given scant attention.

\section{Community forests/joint forest management}

Literature on gender and participatory forest management appeared to focus on three areas: factors affecting women's participation, strengthening women's bargaining power to improve the quality of their participation and the implications of women's participation for sustainability.

Factors that discouraged women's participation included the following:

- Lack of recognition in interpersonal and public spheres, which exacerbates women's sense of powerlessness (Sunam and McCarthy 2010)

- Education, household affluence and conservation attitudes (Baral and Heinen 2007, Gupte 2003).

- Ineffective communication networks such as topdown approaches that lack feedback mechanisms (Otsyina 2002).

- Unwilling participation on executive committees to fulfil donor or NGO requirements, or selection by male executive committee members without their consultation and consent (Agarwal 2001).

- Inequitable distribution of costs and benefits between men and women (Agarwal 2001, 2009, 2010a, Otsyina 2002).

- Social norms that discriminate against women, women's own class, caste, wealth and literacy, and disdain by men of women's contributions (Agarwal 2010b).

Factors that encouraged women's participation included the following:

- Concrete benefits, free interaction between men and women and social norms that do not discriminate against women's involvement in decision making (Nuggehalli and Prokopy 2009).

- Viewing participation as an ongoing and open-ended process of social change rather than a predefined outcome (Giri and Darnhofer 2010a).

- Out-migration of men to cities or other areas (Djoudi and Brockhaus 2011, Giri and Darnhofer 2010b).

- Religion and wealth (Jewitt 2000).

Strategies to improve women's bargaining power so that their participation can actually influence decisions included the following:
- Increasing women's numbers in meetings and committees to build a critical mass, encouraging women to speak up (Agarwal 2001, 2010a, 2010b).

- Integrating men and women into the same group since separate women's groups sharpen segregation (Agarwal 2001).

- Accompanying an increased number of women in decisionmaking committees with capacity building.

- Recognising that some rural women who live in forestry settings may not want to take part in forest- or land-related issues (Jewitt 2000, Resurreccion 2006).

\section{Livelihoods, incomes, markets and commercialisation of forest products}

Of the 26 publications, 17 were focused on Africa. One group of studies examined the value of forest products to rural livelihoods, and how men and women view this value differently. Another group focused on explaining gendered use of forest products, as well as the impacts of their market and commercialisation. The studies showed:

- NTFPs played different roles in mitigating wealth inequality (Fu et al. 2009).

- Income from NTFP activities was important to rural communities; however, men, the elderly and the well-off were more involved in the formal market, while women and children were more engaged in the informal sector (Madi et al. 2010).

- Women depended more on income from NTFPs since they had less access to alternative income (Ajonina et al. 2005, AvocevouAyisso et al. 2009, Fu et al. 2009, Kanmegne et al. 2007).

- Trees within the homestead area provided many functions to rural households, but female-headed households had significantly fewer trees than their male-headed counterparts (Shackleton et al. 2008).

- Men controlled more of the market value-chain since women lacked technology, rights and access to resources even though their contribution was significant (Ajonina et al. 2005, Quang and Anh 2006). Awono et al. (2010) and Perez et al. (2002) suggested that, given the right conditions, women entrepreneurs could be as successful as men.

- Commercialisation of forest products led to overharvesting, which in turn led to more stringent laws and regulations to control harvesting, which subsequently limited women's access to forests (Avocevou-Ayisso et al. 2009, Brown and Lassoie 2010, Madi et al. 2010).

\section{Tenure and property rights: resource access/resource extraction conflict}

Eight publications examined this theme, including the following:

- Veuthey and Gerber (2010) demonstrated that men's control over production tools influenced the division of labour, as well as women's access to forests.

- Recent studies in Nigeria found that women's access to firewood and forest fruit was restricted on communal and family lands, although women had unrestricted access to fodder, snails and mushrooms (Adedayo et al. 2010).

- Howard and Nabanoga (2007) found that Ugandan women needed men's permission to plant trees and harvest them for subsistence use. 
- Coulibaly-Lingani et al. (2009) revealed how laws forbidding forest grazing, along with customary rules and regulations for land tenure, constrained access to forest for both women and migrants.

\section{Men's and women's roles and perceptions in forest management}

The 20 publications were a mix of theoretical and empirical studies. Some empirical studies highlighted the importance of involving women in diverse programmes and projects such as afforestation to combat desertification (Medugu et al. 2010); others focused on institutional issues such as the influence of gender in the formation of forestry-related values in ecosystem goods and services (Farreras et al. 2005). Still others proposed strategies to enhance gender mainstreaming in forestry agencies (Gurung 2002).

\section{Forest resource degradation}

Six studies focused on reducing pressure on forests in fuelwoodscarce areas and understanding gendered relationships in deforestation processes. For example, Allen (2001) found land and forest degradation exacerbated historical inequalities between men and women, aggravated existing challenges and created new ones for women such as reducing the amount and quality of drinking water.

\section{Traditional knowledge, use and management of forest products}

Latin America had the most publications under this theme. Most studies examined the traditional knowledge of different groups of men and women on the forests they lived in - across age, ethnicity, caste, class and religion. The research was intended to encourage medical discovery and raise awareness of how traditional knowledge could contribute to forest biodiversity conservation.

\section{Methods used to integrate gender}

Researchers used common qualitative methods to collect data, including on-site observation, questionnaires/interviews (semistructured, structured, or open-ended), key informant interviews and focus groups. In addition, participatory approaches included participatory rural appraisal, rapid rural appraisal, transect walks, participatory mapping and diagnostic checklists. For quantitative analysis, researchers used surveys for data collection and applied statistical analysis - from descriptive statistics to more advanced regressions.

Participatory approaches in gender research are becoming more popular. However, if researchers are unaware of social rules, norms and power dynamics, they risk excluding women (Agarwal 2001, Gupte 2004). This risk is particularly high in household surveys; many researchers assume that household income is distributed equally (Coe 2008). But men and women have different preferences and opportunities, making households an arena of intense competition over resources (Alderman et al. 1995, Falkingham and Baschieri 2009).
Despite extra time and cost to their work, researchers are increasingly using intra-household surveys (Quisumbing 2004). These studies, however, generally overlook the multiple dimensions of gender at play in both the household and community. Nightingale (2011) and Rocheleau (2008) point out gender dynamics are connected across governance levels; this is critical, since national and international policy decisions often carry implications for local practices.

\section{Gaps in research}

The focus on gender in community forestry reflects the trend towards devolution and decentralisation in forest management over the past 10 years. In developing countries, particularly South Asia, researchers have shown that women's participation can enhance forest sustainability. Building on these results, they are testing the effects of critical mass on women's effectiveness in decision making.

Still, gaps in research remain, including the following issues:

- Types of governance that enable more women to make decisions (Acharya and Gentle 2006).

- Distribution of responsibility, benefits and information between men and women in mixed groups.

- Implications of reforms on women's rights to trees and forest resources and, ultimately, on the security of their rights and access.

- Relative roles and contributions of women and men with respect to collective action and any constraints in forestry settings.

- Gender-differentiated impacts of emerging global processes and policies such as climate mitigation and adaptation, as well as global investments in biofuels.

- Mechanisms to ensure benefits from global processes accrue to women and men equitably, as well as understanding the relative roles of women and men in monitoring, recording and verification of REDD schemes.

- Incentives to improve implementation of gender-sensitive policies in both the formal forestry sector and civil society organisations.

\section{Conclusion}

Integration of gender into forestry still faces several constraints: the broad perception that forestry is a male-dominated profession; lack of clarity among researchers about the concept of gender; and a lack of technical skills, interest and/or awareness of gender. Yet a point raised by earlier researchers continues to resonate: researchers must address gender power relations and dynamics in addition to collecting sex-disaggregated data. Clearly, in this inter-connected global setting, what's required is a framework for systematic investigation of the complexities underpinning women's rights and access to forests, as well as their participation in forest decisionmaking and benefits.

\section{Acknowledgements}

We acknowledge the support of the Austrian Development Agency and the Government of The Netherlands. Four anonymous reviewers also provided useful comments. Errors are our own. We thank Mark 
Foss for a careful editing of the Infobrief. This brief is based on Mai, Y.H., Mwangi, E. and Wan, M. 2011 Gender analysis in forestry research: looking back and thinking ahead. International Forestry Review Vol.13(2): 245-258.

\section{References}

Acharya, K.P. and Gentle, P. 2006 Improving the effectiveness of collective action: sharing experiences from community forestry in Nepal. Capri working paper no 54. International Food Policy Research Institute, Washington DC.

Adedayo, A.G., Oyun, M.B. and Kadeba, O. 2010 Access of rural women to forest resources and its impact on rural household welfare in north central Nigeria. Forest Policy and Economics 12(6): 439-450.

Agarwal, B. 2001 Participatory exclusions, community forestry, and gender: an analysis for South Asia and a conceptual framework. World Development 29(10): 1623-1648.

Agarwal, B. 2009 Gender and forest conservation: the impact of women's participation in community forest governance. Ecological Economics 68: 2785-2799.

Agarwal, B. 2010a Does women's proportional strength affect their participation? Governing local forests in South Asia. World Development 38(1): 98-112.

Agarwal, B. 2010b Gender and green governance: the political economy of women's presence within and beyond community forestry. Oxford University Press, UK.

Ajonina, P.U., Ajonina, G.N., Jin, E., Mekongo, F., Ayissi, I. and Usongo, L. 2005 Gender roles and economics of exploitation, processing and marketing of bivalves and impacts on forest resources in the Sanaga Delta region of Douala-Edea wildlife reserve, Cameroon. International Journal of Sustainable Development and World Ecology 12(2): 161-172.

Alexiades, M.N. and Shanley, P. (eds.) 2004 Producto forestales, meditos de subsistencia y conservacion, estudios de caso sobre sisternas de manejo de productos forestales no maderables. Volumen 3-America Latina. Center for International Forestry Research, Bogor, Indonesia.

Alderman, H., Hoddinott, J., Haddad, J.L. and Udry, C. 1995 Gender differentials in farm productivity. FCND discussion papers No. 6. International Food Policy Research Institute, Washington, DC.

Allen, R. 2001 Strategies to address land degradation issues in the Hindu Kush-Himalayas. In: Bridges, E.M., Hannam, I.D., Oldeman, L.R., Devries, W.T.P., Scherr, S.J. and Sombatpanit, S. (eds.) Response to land degradation. Science Publishers Inc., Enfield, US.

Avocevou-Ayisso, C., Sinsin, B., Adegbidi, A., Dossou, G. and Van Damme, P. 2009 Sustainable use of non-timber forest products: impact of fruit harvesting on Pentadesma butyracea regeneration and financial analysis of its products trade in Benin. Forest Ecology and Management 257(9): 1930-1938.

Awono, A., Ndoye, O. and Preece, L. 2010 Empowering women's capacity for improved livelihoods in nontimber forest product trade in Cameroon. International Journal of Social Forestry 3(2): 151-163.

Baral, N. and Heinen, J.T. 2007 Decentralization and people's participation in conservation: a comparative study from the western Terai of Nepal. International Journal of Sustainable Development and World Ecology 14(5): 520-531.

Brown, H.C.P. and Lassoie, J.P. 2010 The interaction between market forces and management systems: a case study of non-wood forest products in the humid forest zone of Cameroon. International Forestry Review 12(1): 13-26.

CGIAR Science Council 2009 Stripe review of social sciences in the CGIAR. Science Council Secretariat, Rome.

Coe, K. 2008 The significance of donor gender equality policies in natural resource management research. MA thesis. Institute of Advanced
Studies, School for Environmental Research, Charles Darwin University, Australia.

Colfer, J.P.C. (ed.) 2005a The equitable forests: diversity, community and resource management. Resources for the future, Washington, DC.

Colfer, J.P.C. 2005b The complex forest: communities, uncertainty and adaptive collaborate management. Resources for the future, Washington, DC.

Colfer, C.J. and Capistrano, D. (eds.) 2005. The politics of decentralization: forests, power and people. Earthscan, London.

Coulibaly-Lingani, P., Tigabu, M., Savadogo, P., Oden, P.C. and Ouadba, J.M. 2009 Determinants of access to forest products in southern Burkina Faso. Forest Policy and Economics 11: 516-524.

Djoudi, H. and Brockhaus, M. 2011 Vulnerability to climate variability and change among communities depending on livestock and forest in northern Mali: a cross-scale analysis. Paper to the Thirteenth Biennial Conference of the International Association for the Study of Common (IASC), 10-14 January 2011.

FAO 2007 Gender mainstreaming in forestry in Africa. Report of a project carried out under the FAO Netherlands partnership program. Food and Agriculture Organization of the United Nations, Rome.

Fajber, L. and Vernooy, R. 2006 From voice to voice: lessons from a regional capacity development initiative to strengthen social and gender analysis in participatory natural resources management research. International Journal of Agricultural Sustainability 4(2): 143-153.

Falkingham, J. and Baschieri, A. 2009 Gender and poverty: how misleading is the unitary model of household resources? In: Yeates, N. and Holden, C. (eds.) The global social policy reader, 123-128. The Policy Press, Bristol, UK.

Farreras, V., Riera, P. and Mogas, J. 2005 Does gender matter in valuation studies? Evidence from three forestry applications. Forestry 78(3): 239-248.

Fu, Y.N., Chen, J., Guo, H.J., Hu, H.B., Chen, A.G. and Cui, J.Y. 2009 Rain forest dwellers' livelihoods: income generation, household wealth and NTFP sales, a case study from Xishuangbanna, SW China. International Journal of Sustainable Development and World Ecology 16(5): 332-338.

Giri, K. and Darnhofer, I. 2010a Nepali women using community forestry as a platform for social change. Society \& Natural Resources 23(12): $1216-1229$.

Giri, K. and Darnhofer, I. 2010b Outmigrating men: a window of opportunity for women's participation in community forestry? Scandinavian Journal of Forest Research 25: 55-61.

Gupte, M. 2003 Reexamining participatory environmental policy: social stratification and the gender dimension. Society \& Natural Resources 16(4): 327-334.

Gupte, M. 2004 Participation in a gendered environment: the case of community forestry in India. Human Ecology 32(3): 365-382.

Gurung, D.J. 2002 Getting at the heart of the issue: challenging male bias in Nepal's Department of Forests. Mountain Research and Development 22(3): 212-215.

Hecht, S.B. 2007 Factories, forests, fields and family: gender and neoliberalism in extractive reserves. Journal of Agrarian Change 7(3): 316-347.

Hovorka, A.J. 1998 Gender resources for urban agriculture research: methodology, directory and annotated bibliography. Cities Feeding People series. Report 26, International Development Research Centre, Ottawa, Canada.

Howard, L.A. and Nabanoga, G. 2007 Are there customary rights to plants? An inquiry among the Baganda (Uganda), with special attention to gender. World Development 35(9): 1542-1563.

Jewitt, S. 2000 Unequal knowledge in Jharkhand, India: de-romanticizing women's agro-ecological experience. Development and Change 31(5): 961-985. 
Kanmegne, J., Belinga, J.M.O., Degrande, A., Tchoundjeu, Z. and Manga, T.T. 2007 Gender analysis in the commercialization of Gnetum africanum/buchholzianum in the Lekie division in Cameroon. Journal of food, agriculture and environment 5(1): 243-247.

Kusters, K. and Belcher, B. (eds.) 2004 Forest products, livelihoods and conservation: case studies of non-timber forest products systems. Volume 1-Asia. Center for International Forestry Research, Bogor, Indonesia.

Lyren, L. 2006 Gender and forestry: a bibliography. Forestry library. Faculty of Forest Sciences, Swedish University of Agriculture Sciences, Umea, Sweden.

Madi, O.P., Peltier, R., Balarabe, O., Ntoupka, M. and Sibelet, N. 2010 Should north Cameroon's acacia plantations be abandoned or extended? It all depends on development of the arabic gum market chain. Bois et forets des tropiques 306: 57-70.

Magnus, E. 2003 Gender analysis in NRSP. Department for International Development (DFID) Natural Resources Systems Programme (NRSP) development report PD123. NRSP, Hemel Hempstead, UK.

Mai, H.Y. and Mwangi, E. In press. Incorporating gender in CIFOR's research: a review of CIFOR's gender analysis. CIFOR working paper. Center for International Forestry Research, Bogor, Indonesia.

Medugu, N.I, Majid, M.R., Johar, F. and Choji, I.D. 2010 The role of afforestation programme in combating desertification in Nigeria. International Journal of Climate Change Strategies and Management 2(1): 35-47.

Nightingale, A.J. 2011 Bounding difference: intersectionality and the material production of gender, caste, class and environment in Nepal. Geoforum 42(2): 153-162.

Nuggehalli, R.K. and Prokopy, L.S. 2009 Motivating factors and facilitating conditions explaining women's participation in co-management of Sri Lankan forests. Forest Policy and Economics 11: 288-293.

Otsyina, J.A. 2002 Information communication and community forestry development in Shinyanga. Discovery and Innovation, special issue: 82-89.

Perez, M.R, Ndoye, O., Eyebe A. and Ngono, D.L. 2002 A gender analysis of forest product markets in Cameroon. Africa Today: 97-126.

PRB 2001 Women, men, and environmental change: the gender dimensions of environmental policies and programs. Population Reference Bureau, Washington, DC.
Quang, D.V. and Anh, T.N. 2006 Commercial collection of NTFPs and households living in or near the forests: case study in Que, Con Cuong and $\mathrm{Ma}$, Tuong Duong, Nghe An, Vietnam. Ecological Economics 60(1): 65-74.

Quisumbing, R.A. 2004 Household decision, gender and development: a synthesis of recent research. International Food Policy Research Institute, Washington, DC.

Reeves, H. and Baden S. 2000 Gender and development: concepts and definitions. Bridge report No. 55. Institute of Development Studies, Sussex University, UK.

Resurreccion, P.B. 2006 Gender, identity and agency in Philippine upland development. Development and Change 37(2): 375-400.

Ribot, Jesse C. and Larson, A.M. (eds.) 2005 Democratic decentralisation through a natural resources lens. Routledge, London.

Rocheleau, D.E. 2008 Political ecology in the key of policy: from chains of explanation to webs of relation. Geoforum 39: 716-727.

Shackleton, C.M., Paumgarten, F. and Cocks, M.L. 2008 Household attributes promote diversity of tree holdings in rural areas, South Africa. Agroforestry Systems 72(3): 221-230.

Sunam, R.K. and McCarthy, J.F. 2010 Advancing equity in community forestry: recognition of the poor matters. International Forestry Review 12(4): 370-382.

Sunderland, T. and Ndoye, O. (eds.) 2004 Forest products, livelihoods and conservation: case studies of non-timber forest products systems, Volume 2-Africa. Center for International Forestry Research, Bogor, Indonesia.

Veuthey, S. and Gerber, J.F. 2010 Logging conflicts in southern Cameroon: a feminist ecological economics perspective. Ecological Economics 70(2): 170-177.

Watson, E. 2005 Gender sensitive natural resource management (NRM) research for development. Department for International Development (DFID) Natural Resources Systems Programme (NRSP) development report PD123. Gender sensitive NRM research for development. Department of Geography, University of Cambridge, UK.

World Bank 2000 World Development Report: attacking povertyopportunity, empowerment and security. World Bank, Washington, DC.

This research was carried out as part of the CGIAR Research Programme, 'Forests, Trees and Agroforestry: Livelihoods, Landscapes and Governance'. The Programme aims to enhance management and use of forests, agroforestry and tree genetic resources across the landscape from forests to farms. The Center for International Forestry Research leads the collaborative programme in partnership with Bioversity International, the International Center for Tropical Agriculture and the World Agroforestry Centre.

\section{Austrian \\ Development Agency

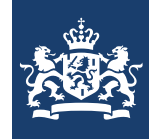

